\title{
FUNDING LIQUIDITY RISK in a Quantitative Model of Systemic Stability
}

\author{
David Aikman, Piergiorgio Alessandri, \\ Bruno Eklund, Prasanna Gai, Sujit Kapadia, \\ Elizabeth Martin, Nada Mora, \\ Gabriel Sterne, Matthew Willison \\ Bank of England, Federal Reserve Bank of Kansas City, \\ and Australian National University
}

The global financial crisis of 2007-09 has illustrated the importance of including funding liquidity feedbacks in any model of systemic risk. This paper illustrates how we have incorporated such channels into a risk assessment model for systemic institutions (RAMSI), and it outlines the Bank of England's plans to use RAMSI to sharpen its assessment of institution-specific and systemwide

All authors are with the Bank of England except Prasanna Gai, who is with the Australian National University, and Nada Mora, who is with the Federal Reserve Bank of Kansas City. The RAMSI project represents a major investment of Bank of England resources, and we are grateful to many people both inside and outside the Bank of England for their contributions. In particular, the National Bank of Austria has been very generous in providing guidance and significant analytical contributions. The analysis in this paper has benefited from encouragement and contributions from Viral Acharya, Niki Anderson, Marnoch Aston, Richard Barwell, Emily Beau, Michael Boss, John Carmichael, Ethan Cohen-Cole, Geoff Coppins, Sebastiano Daros, Paul Doran, Mathias Drehmann, John Elliott, Helmut Elsinger, David England, Phil Evans, Antonella Foglia, Celine Gauthier, Brenda Gonzalez-Hermosillo, Charles Goodhart, Andy Haldane, Simon Hall, Jen Han, Florence Hubert, Gregor Irwin, Charles Khan, David Lando, Nigel Jenkinson, Rob Johnson, Charles Kahn, Sandhya Kawar, Will Kerry, Jack Mckeown, Alex McNeil, Andrew Mason, Colin Miles, Pierre Monnin, Haroon Mumtaz, Emma Murphy, Gareth Murphy, Rain Newton-Smith, Joseph Noss, Spyros Pagratis, Andrew Patton, Adrian Penalver, Silvia Pezzini, Laura Piscitelli, Claus Puhr, Victoria Saporta, Til Schuermann, Miguel Segoviano, Jack Selody, Hyun Shin, Steffen Sorensen, George Speight, Marco Stringa, Martin Summer, Ryland Thomas, Dimitri Tsomocos, Iman van Lelyveld, Nick Vause, Lewis Webber, Simon Wells, and Peter Westaway. Harry Goodacre, Tony Lee, and Emma Mattingley provided excellent research assistance.

Financial Stability, Monetary Policy, and Central Banking, edited by Rodrigo A. Alfaro, Santiago, Chile. (C) 2010 Central Bank of Chile. 
vulnerabilities. The model focuses on the health of core banks in the U.K. financial system. For these banks, the model provides a coherent quantitative framework for assessing how shocks transmit through balance sheets, allowing for macro-credit risk, interest and noninterest income risk, network interactions, and feedback effects arising on both the asset and liability side of the balance sheet. Systemic risks stem from the connectivity of bank balance sheets via interbank exposures (counterparty risk); the interaction between balance sheets and asset prices (fire-sale effects); and confidence effects that may affect funding conditions.

Central banks and regulators are increasingly seeking to use formal models to support their financial stability work, and various approaches have emerged in recent years (Jenkinson, 2007). Senior policymakers at the Bank of England have for some time expressed a desire for an integrated approach to assessing systemic risk (Gieve, 2006). Gai and Haldane (2007) provide motivation for a new approach that emphasizes the importance of distinguishing probability and impact when conducting risk assessment work, and the Bank of England's preliminary implementation of such a framework is discussed by Haldane, Hall, and Pezzini (2007).

RAMSI aims to deliver a suite of models that should support a substantial enhancement in the Bank of England's ability to conduct risk assessment in a rigorous and consistent quantitative framework, thus helping to sharpen the analysis of key vulnerabilities and to improve the Bank's capability to influence and strengthen the management of these risks. Internally, RAMSI will support discussions of key risks on a bank-by-bank and systemwide basis, and it will facilitate examining the impact of various policy measures. Externally, the outputs from the suite of models will be a source for communicating risk assessment messages to risk managers in the financial sector, thereby helping shape their attitudes toward risk.

The analytical foundations of RAMSI draw, in particular, on two strands of literature. First, it employs elements of the traditional stress-testing literature, which tend to focus on credit risk on a bank's balance sheet (see Foglia, 2009; Borio and Drehmann, in this volume). Second, it draws on recent theoretical work on modeling systemic financial crises. Allen and Gale (2000) explore the spread of contagion in a banking network, and Cifuentes, Ferrucci, and Shin (2005) examine how default across 
the network is amplified by asset price effects. Gai and Kapadia (2010; in this volume) examine the nonlinearities implied by these externalities and suggest that financial innovation may have increased the severity of crises. ${ }^{1}$

The modular approach involves feeding shocks and scenarios from a macroeconomic model through several distinct balance-sheetbased models that describe how risk profiles evolve throughout banks' business operations. It is influenced by the framework developed by the National Bank of Austria (Boss and others, 2006) for the Austrian banking system (see also Elsinger, Lehar, and Summer, 2006a), which integrates balance-sheet-based models of credit and market risk with a network model to evaluate the probability of bank default. In presenting a prototype version of RAMSI, Alessandri and others (2009) extended and developed the single-period Austrian model in a number of dimensions. In a multiperiod setting, they incorporated net interest income and feedback effects associated with asset fire sales following bank default.

This paper extends the RAMSI prototype in several ways, including the use of richer balance sheets, a more powerful macroeconomic model, better modeling of credit risk, and a model of noninterest (nontrading) income. The main innovation, however, relates to the role of liability-side feedbacks. We develop a twopronged framework for modeling funding liquidity risk. In the first stage, we apply an empirical model to project individual bank ratings, and we then use the results to calibrate how funding costs may rise as a bank's position worsens. In the second stage, we calibrate the onset of funding crises and outright closure of funding markets to particular institutions based on a series of indicators. To inform our analysis, we draw on theoretical models, information from banks' own liquidity policies, and evidence both from past episodes of funding stress and from recent experience, including the failure of Northern Rock.

RAMSI's framework is particularly attractive to central banks because of its storytelling capacity. Alternative approaches to the analysis of systemic risk offer particular strengths, either in terms of micro-foundations or in terms of consistency with market-based

1. This result is reinforced by Gai and others (2008), who demonstrate how financial innovation and macroeconomic stability may have intensified the robust-yet-fragile nature of the banking system. 
pricing of risk. ${ }^{2}$ Although RAMSI's framework relies on reducedform estimation and behavioral rules of thumb, it offers a flexible and operational means of capturing a wide range of risks and transmission channels, and it allows for a more articulated analysis and interpretation of the outputs of stress-testing exercises.

The structure of the paper is as follows. Section 1 describes the current components of RAMSI and explains how they fit together. Section 2 discusses the aggregate distributions obtained from stochastic simulation and conducts a detailed analysis of a particular realization in which funding liquidity feedbacks contribute to systemwide stress. Section 3 discusses how RAMSI will improve the quality of risk assessment work, and section 4 concludes.

\section{The Modeling Framework}

Figure 1 illustrates the modular structure of RAMSI and the mapping from shocks to systemic risk. The transmission dynamics hinge crucially on two factors - the nature and scale of shocks and the structural characteristics of the financial system. In such an environment, balance sheet interdependencies and asset- and liabilityside feedbacks make for complex, nonlinear behavior. RAMSI produces asset distributions for individual banks and for the aggregate banking system by linking together the shaded modules presented in figure 1. The unshaded module (that is, feedbacks to the macroeconomy) is mentioned briefly in the conclusion, but it is mainly left for future work. In what follows, we discuss the overall modeling strategy in RAMSI before briefly discussing each of its components.

At the core of RAMSI are detailed end-2007 balance sheets of the ten largest U.K. banks. ${ }^{3}$ These link the modules to the structure of

2. For example, Goodhart, Sunirand, and Tsomocos (2006) provide a general equilibrium framework, but the model is stylized and difficult to operationalize. The asset pricing approach, in turn, extracts risk from observed security prices. This approach can be applied to individual banks (Segoviano and Padilla, 2006; Elsinger, Lehar, and Summer, 2006b; Frisell and others, 2007) or to sectors of the economy (Gray, Merton, and Bodie, 2007). These models provide timely updates to banks' risk profiles, albeit on the basis of strong assumptions on market completeness and efficiency. Furthermore, market prices may embed the possibility of official support, so the asset pricing approach may be unable to identify the extent to which intervention helps to mitigate systemic risks (Birchler and Facchinetti, 2007).

3. Membership of the major U.K. banks group is based on the provision of customer services in the United Kingdom, regardless of country of ownership. At year-end 2007, the members were Alliance and Leicester, Banco Santander, Barclays, Bradford and Bingley, Halifax Bank of Scotland, HSBC, Lloyds TSB, Nationwide, Northern Rock, and Royal Bank of Scotland. 


\section{Figure 1. RAMSI Framework}

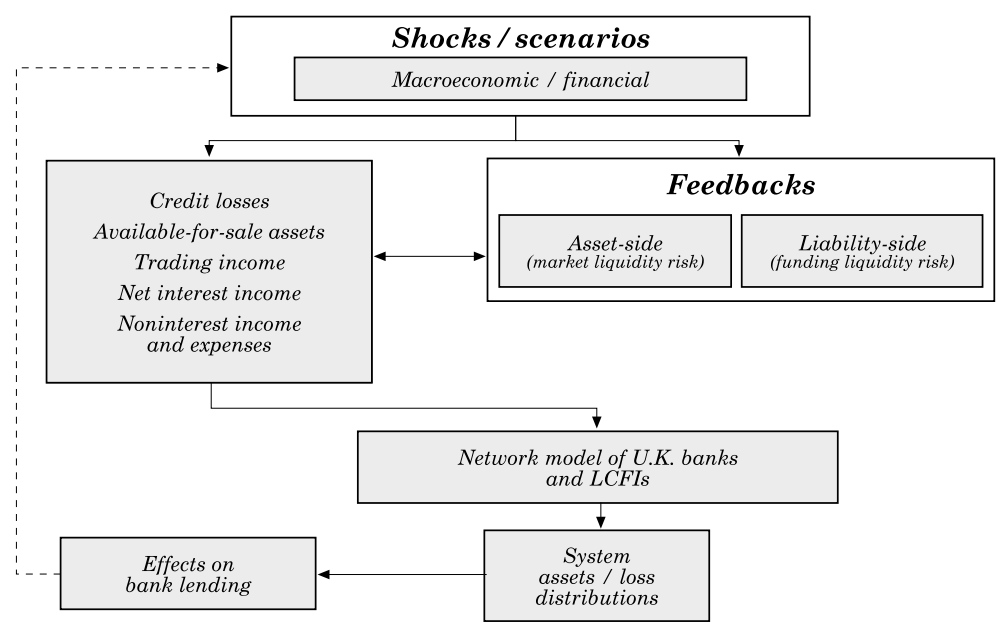

Source: Authors' assessment.

individual U.K. banks. The balance sheets are highly disaggregated, with approximately 650 balance sheet entries (including 400 asset classes and 250 liability classes). Each of the asset and liability classes are further disaggregated into five maturity buckets and six repricing buckets. ${ }^{4}$ Data are mainly extracted from regulatory accounts but are supplemented from regulatory returns. This modeling of individual bank balance sheets supports an analytically rich model and allows us to examine, in detail, the likely sources of profits and losses on a disaggregated and aggregated basis. Not all of the balance sheet entries are available, so we use rules of thumb based on other information or extrapolations on the basis of our knowledge of similarities between banks to fill in the data gaps. Much of the granularity arises from decomposition of the trading book and available for sale (AFS) assets. Since the focus of this paper is on the role of funding liquidity risk, we do not model these exposures here. However, this part of the balance sheet has played an important role in the ongoing financial crisis, and we believe that no systemic risk model can credibly ignore it. Trading book and AFS models are currently under development and will be introduced in the next version of RAMSI.

4. We do not have six repricing buckets for each of the five maturity buckets. 
The model is run over a three year horizon, which is sufficient time for some adverse shocks to be reflected in credit losses (Bunn, Cunningham, and Drehmann, 2005; DNB, 2006) and is consistent with the horizon central banks often use when stress testing their financial systems (Hagen and others, 2005; Bank of England, 2007; Sveriges Riksbank, 2007). The sequence of events is illustrated in figure 2. Outcomes from a macroeconomic model determine a yield curve and probabilities of default and loss-given default on banks' credit exposures. For each combination of risk factors, we model the first-round effects on each bank, with distinct modules accounting for credit losses, net interest income, other income, and operating expenses.

\section{Figure 2. Model Dynamics ${ }^{a}$}

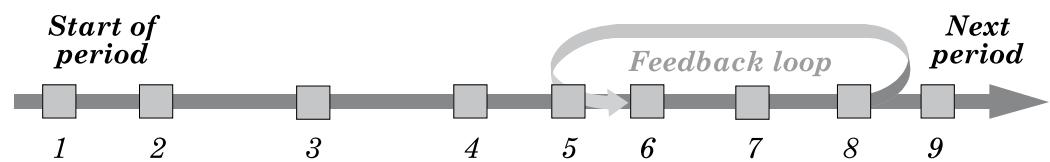

1 Macro/financial shocks

2 PDs and yields

3 Balance sheet adjustment Trading book (AFS) Loan book (credit losses)

4 Profit and loss Trading income Net interest income Other income Operating costs Tax and dividends
5 Rating model

6 Funding liquidity / bank failure check

7 Liquidity feedbacks Asset fire sales Funding (confidence)

8 Network losses

9 Reinvestment

Source: Authors' drawing.

a. The trading book and available-for-sale (AFS) assets are not included in this version of RAMSI.

If a bank's fundamentals deteriorate, its rating may be downgraded, increasing its future funding costs. In severe circumstances, funding conditions may deteriorate to such an extent that the bank is shut out of short-term funding markets. It then fails, triggering a feedback loop. Because of bankruptcy costs, a fraction of the failed bank's assets are lost, reducing the amount available to its creditors on the interbank network. Some of the bank's assets are sold at fire-sale prices, creating asset-side feedbacks that cause remaining banks to suffer temporary (intraperiod) mark-to-market losses. Funding markets suffer confidence contagion that makes banks with similar characteristics to the failed bank more vulnerable 
to being shut out of funding markets. If a further bank fails after we account for the second-round effects, then the loop repeats until the default cascade ends.

In the absence of bank failures (or after the feedback loop has completed), we update the balance sheets of surviving banks using a rule of thumb for reinvestment behavior. Banks target prespecified Tier 1 capital ratios, and they invest in assets and increase liabilities in proportion to their shares on their initial balance sheet.

Throughout the paper, we assume that there is no regulatory or other policy intervention, aside from the interest rate response that is endogenous to the macroeconomic model. This is partly because modeling the policy reaction to extreme events is inherently difficult, especially given that there is no single, standard response to financial crises. The model therefore provides an assessment of how the financial system would fare without any policy response. This allows for judgements to be drawn on the potential benefits and costs of intervening.

\subsection{The Macroeconomic Model}

The link between the macroeconomy and the various risks on banks' balance sheets is central to RAMSI. We use a large-scale Bayesian vector autoregression (BVAR) to capture the evolution of macroeconomic and financial variables. The BVAR is the only source of shocks in RAMSI, thereby preserving a one-for-one mapping from macroeconomic variables to default risk, which is useful for storytelling purposes. ${ }^{5}$

The BVAR is estimated on quarterly data over the sample period from the second quarter of 1972 to the fourth quarter of 2007. The model includes 24 domestic and foreign (U.S. and E.U.) variables (see table 1) and has two lags. We use quarterly growth rates of all variables, barring those denoted with an asterisk. The resulting vector of time series variables to be modeled therefore contains a mixture of levels and growth rates, including the quarterly growth of gross domestic product (GDP), the level of the three-month Treasury bill rate, and so on. Our prior treats every variable in the system as a white noise process centered around a constant. This is a special case of the Minnesota prior popularized by Litterman (1986): essentially,

5. Stress scenarios can be used to determine the impact of adjusting nonmacroeconomic variables and model parameters. 
Table 1. List of BVAR Variables

\begin{tabular}{|c|c|c|}
\hline \multirow[b]{2}{*}{$\begin{array}{l}\text { Country } \\
\text { or region }\end{array}$} & \multicolumn{2}{|c|}{ Variable } \\
\hline & $\begin{array}{l}\text { In quarterly } \\
\text { growth rates }\end{array}$ & In levels \\
\hline \multirow[t]{8}{*}{ United Kingdom } & Real GDP & Three-month Treasury bill rate \\
\hline & CPI inflation & Three-year government bond rate \\
\hline & $£$ ERI & Ten-year government bond rate \\
\hline & Real FTSE index, all shares & Unemployment \\
\hline & Real house prices & Income gearing \\
\hline & Real commercial prop. prices & Corporate lending \\
\hline & & Three-month LIBOR spread \\
\hline & & Ten-year corporate spread \\
\hline \multirow[t]{2}{*}{ United States } & Real GDP & Three-month Treasury bill rate \\
\hline & CPI & Three-year government bond rate \\
\hline \multirow[t]{2}{*}{ Euro area } & Real GDP & Three-month Treasury bill rate \\
\hline & CPI & Three-year government bond rate \\
\hline \multirow[t]{2}{*}{ World } & Real oil prices & \\
\hline & Real world equity prices & \\
\hline
\end{tabular}

Source: Authors' compilation.

we adapt the standard Minnesota prior to the case where all unit roots have been eliminated by data transformations. ${ }^{6}$

The BVAR performs well according to the usual diagnostics. First, it has reasonable in-sample fit, capturing much of the variation over time in most series (the average $R$ squared across the 24 equations was 66 percent). The equations for asset prices had the poorest fit, including equities, the sterling exchange rate index (ERI), and particularly oil prices ( $R$ squared of 12 percent). Second, the forecasts are, for the most part, reasonable: most variables are projected to either regress back to their average historical growth rates or to gradually converge on their sample means. Third, the model also produces reasonable impulse responses following shocks to U.K. GDP, U.K. three-month interest rates, U.K. house prices, and real oil prices.

6. In a Bayesian context, all parameters are treated as random variables and the data are used to estimate their probability distribution rather than to obtain point estimates. We abstract from model uncertainty and use the means of the estimated posterior parameter distributions. 
For simplicity, we approximate the yield curve by linearly interpolating the short- and long-term interest rates implied by the BVAR (two for the United Kingdom and one each for the euro area and the United States). This is the source of all risk-free rates used in the model. Finally, since the BVAR does not forecast the spread on the London interbank offered rate (LIBOR) particularly well, we currently assume that it evolves according to the path implied by forward spreads.

\subsection{First-Round Impact on Banks}

In this section we assess the first-round impact of shocks on banks, before the impact of any systemic interactions.

\subsubsection{Credit risk}

The credit risk module treats aggregate default probabilities (PDs) and loss given default (LGD) as a function of the macroeconomic and financial variables from the BVAR. Credit losses are derived as the product of the relevant aggregate PD times LGD times each bank's total exposure to the sector. ${ }^{7}$ We adjust the aggregate write-off rate for each bank to account for heterogeneity in the riskiness of banks' portfolios. ${ }^{8}$ We model credit losses arising from exposure to U.K. households (through mortgages, credit cards, and other unsecured borrowing), U.K. corporates, plus households and corporates in the United States, the euro area and the rest of the world. ${ }^{9}$ For brevity, we only report results for U.K. mortgages and corporate loans.

Basing the model on Whitley, Windram, and Cox (2004), we relate the PD on a representative pool of mortgages to the unemployment rate, the level of income gearing (that is, interest payments relative to disposable income), and undrawn equity in housing stock (that is, the residual proportion of housing wealth net of the stock of

7. That is, we model expected credit losses and trace out variation in expected credit losses driven by macroeconomic fundamentals.

8. These adjustments are made on the basis of historical differences between the write-off rates of individual banks and aggregate write-off rates. This implies that a relatively safer bank continues to incur lower credit losses than the typical bank.

9. Data availability poses a major challenge. It would be desirable to capture sectoral concentrations and lumpiness in corporate exposures by modeling a finer breakdown of exposures (such as commercial property lending). Currently, our assumption is that portfolios are infinitely granular. 
mortgage debt). Our dependent variable is the fraction of borrowers who are three months or more in arrears. We model arrears as they provide a forward-looking indicator of actual defaults. We estimate a transition rate based on the average historical relationship between these variables. The model is estimated on a sample running from the early 1980s, reflecting the structural change in retail credit markets following the removal of direct controls on bank lending in 1980 (the so-called corset). The LGD on this pool is assumed to be driven by residential property prices.

Our preferred model of the corporate liquidations rate is driven by real output growth, the real (ex post) cost of borrowing, commercial property prices, and a measure of the cyclical variation in corporate debt (based on Vlieghe, 2001). The LGD on a corporate loan is assumed to depend on the value of commercial property prices.

The estimated coefficients in both equations are all signed according to our priors. Both models capture the broad movements in the data reasonably well, but there are clear areas for improvement. The mortgage arrears equation, for instance, only accounts for around half of the pick up in arrears in the early 1990s, and the performance of the corporate PD equation deteriorates from 2002 onwards. ${ }^{10}$

\subsubsection{Net interest income}

For most of the loan book, interest income is modeled endogenously. Banks price their loans on the basis of the prevailing yield curve and the perceived riskiness of their debtors: an increase in actual or expected credit risk translates into a higher cost of borrowing. However, banks' repricing ability is constrained by the maturity structure of their balance sheets. Since assets and liabilities typically do not have matched maturities, these constraints generate significant income risk. The possibility of shifts in the yield curve intensifies this risk.

We use the risk-neutral asset pricing model of Drehmann, Sorensen, and Stringa (2008) to consistently capture both sources of income risk. Consider a risky asset, $A$, with a repricing maturity equal to $T$, implying that the asset pays a fixed coupon $C$ over the next

10. Possible explanations include the (until recently) prolonged stability of the macroeconomy; the cleansing effect of earlier recessions; legislative changes (namely, the 2000 Insolvency Act and the 2002 Enterprise Act); and (until recently) the easy availability of credit. 
$T$ periods. The economic value of the asset today is the risk-adjusted discounted value of future coupon payments and the principal:

$\mathrm{E} V\left(A_{0}\right)=\sum_{t=1}^{T} D_{t} C A_{0}+D_{T} A_{0}$

where the discount factors are given by

$$
D_{t}=\prod_{l=1}^{t}\left(1+R_{l-1, l}\right)^{-1}
$$

and

$$
R_{l-1, l}=\frac{r_{l-1, l}+P D_{l-1, l} * L G D_{l-1, l}}{1-P D_{l-1, l} * L G D_{l-1, l}}
$$

and where $r_{l-1, l}, P D_{l-1, l}$, and $L G D_{l-1, l}$ represent, respectively, the forward risk-free interest rate, expected $\mathrm{PD}$, and expected LGD between time $l-1$ and $l .{ }^{11} \mathrm{We}$ can use the first equation to calculate a fair time-zero coupon that guarantees that $\operatorname{E} V\left(A_{0}\right)=A_{0}$ :

$$
C=\frac{1-D_{T}}{\sum_{t=1}^{T} D_{T}} .
$$

Whenever the bank can update $C$ (that is, at time $T, 2 T, \ldots$ ), it will do so using the equation above, so that expected interest income covers expected losses and book and economic value coincide. Between 0 and $T$, though, interest rates, PDs, and LGDs may change, whereas the coupon is fixed: any change in discount factors that is unexpected as of time zero will thus prevent the zero-profit condition from holding. For each bank, we use balance sheet information to determine the fraction of assets and liabilities that can be repriced at any point in time. The model implies that the pricing structure of the balance sheet-particularly the mismatch between assets and liabilities_influences a bank's vulnerability to interest rate and PD shocks.

11. The risk-free yield curve is known at the time of pricing; we assume that banks take future PDs and LGDs to be equal to the most recent observations. 
The model-implied coupons are calibrated to better accord with actual observed spreads, as these may also partly reflect compensation for fixed costs associated with arranging loans and oligopolistic profits derived by banks. In particular, for household and nonfinancial sector corporate assets, the model-implied coupon is increased by 50 basis points.

For other parts of the balance sheet, including all of the liability side, we simply calibrate spreads based on market rates and other data. For example, we assume that interbank assets and liabilities receive or pay the risk-free rate plus the LIBOR spread, while banks pay negative spreads relative to the risk-free rate on some household and corporate deposits (if the negative spread implies a negative interest rate, the interest rate paid is assumed to be zero). As discussed below, spreads on certain liability classes may also depend on the rating of the bank in question.

\subsubsection{Noninterest (nontrading) income and operating expenses}

Noninterest, nontrading income (henceforth noninterest income) was just under half of U.K. banks' operating income in $2007 .{ }^{12} \mathrm{It}$ includes fees and commissions (see table 2). Stiroh (2004) finds noninterest income to be procyclical, which appears plausible given that its components include securitizations. Bank-specific and structural determinants may also be important. The rise in the share of noninterest income may be seen in the context of new technologies (such as internet fees), financial derivatives, loan securitizations, and the sale of back-up lines of credit. Capital is not required for many such fee-based activities, even though some, such as derivatives and trust services, take place on balance sheet, so increased reliance on noninterest income could be associated with higher leverage (DeYoung and Rice, 2004).

12. One reason for separating the modeling of trading income from that of the other components of noninterest income is that trading income is the most volatile. It contributes to a large part of the variance of total noninterest income, which itself has increasingly contributed to the variance of overall operating income growth. Stiroh (2004) shows that for U.S. banks, the noninterest income contributed 80 percent of the volatility of operating income in the 1990 s. 
Table 2. U.S. and U.K. Noninterest Income and Expenses ${ }^{a}$ Ratio of operating income

\begin{tabular}{lccc}
\hline United States & $1984-89$ & $1990-99$ & $2000-07$ \\
\hline Net interest income & 0.72 & 0.64 & 0.57 \\
Noninterest income & 0.28 & 0.36 & 0.43 \\
Fiduciary & 0.05 & 0.05 & 0.05 \\
Service charge & 0.06 & 0.07 & 0.07 \\
Trading & 0.02 & 0.03 & 0.03 \\
Other & 0.15 & 0.21 & 0.27 \\
Noninterest expenditure & 0.68 & 0.64 & 0.59 \\
Noninterest, nontrading income & 0.26 & 0.33 & 0.40 \\
\hline United Kingdom ${ }^{b}$ & $1997-2003$ & $2004-06$ & 2007 interim \\
\hline Net interest income & 0.58 & 0.42 & 0.39 \\
Noninterest income & 0.43 & 0.58 & 0.61 \\
Net fees and commissions & 0.27 & 0.20 & 0.21 \\
Dividend income & 0.003 & 0.004 & 0.005 \\
Dealing profits & 0.05 & 0.11 & 0.13 \\
Other & 0.10 & 0.27 & 0.26 \\
Noninterest expenditure & 0.56 & 0.62 & 0.59 \\
Noninterest, nontrading income & 0.38 & 0.47 & 0.48 \\
\hline
\end{tabular}

Source: Authors' calculations.

a. The components of noninterest income are not directly comparable between the United States and the United Kingdom. For example, fees and commissions are included in other noninterest income in the United States. b. In the United Kingdom, the change to International Financial Reporting Standards (IFRS) in 2004 boosted the share of insurance income. For example, Lloyds TSB's noninterest income as a share of its operating income jumped from 47 percent in 2003 to 74 percent in 2004 .

Data paucity and inconsistencies rule out estimation based on U.K. data, so we instead use U.S. data (see table 2). This seems reasonable given the similarities between the United Kingdom and the United States and, in particular, the similar shares of noninterest income in operating income (around 42 percent for U.K. banks and 38 percent for U.S. banks). As in Stiroh (2004), we use aggregate quarterly U.S. data that covers over 7,000 FDIC-insured commercial banks in the period from the first quarter of 1984 to the third quarter of 2007. The use of aggregate data prohibits a search for bank-specific effects.

The results for the favored equation are shown below. As in Stiroh (2004), noninterest income is quite strongly procyclical. A one percentage point increase in real GDP above baseline implies 
that real noninterest income rises by 2.7 percentage points initially and 2.0 percentage points eventually. ${ }^{13} \mathrm{We}$ find insufficiently strong evidence for factors such as balance sheet asset growth, equity returns, and equity volatility to include them in RAMSI. However, some specifications (not shown) provided evidence that noninterest income increases with leverage and decreases with the slope of the yield curve.

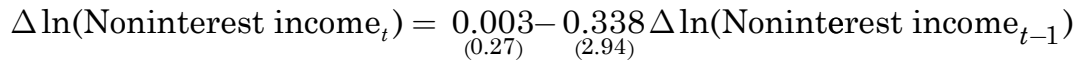

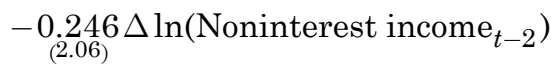

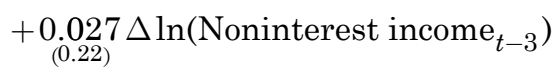

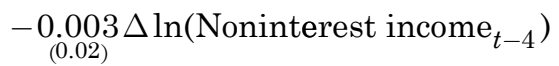

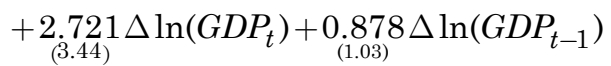

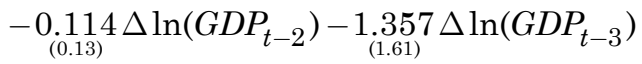

$$
\begin{aligned}
& +\underset{(1.19)}{1.003} \Delta \ln \left(G D P_{t-4}\right) \text {, }
\end{aligned}
$$

where the joint significance of GDP and lagged GDP ( $p$ value) is 0.004 and the adjusted $R$ squared is 0.18 , based on 90 observations.

We validate the U.S.-based model on U.K. data by checking its forecasting performance. We generate noninterest income forecasts for each U.K. bank based on its initial level and increase that with the predicted values of real noninterest income growth from the estimated equation. When calibrated to U.K. banks, the out-ofsample forecasting performance is satisfactory. Between 2005 and 2007 , the model predicts a 16.5 percent increase over the two years, compared with an outturn of 16.2 percent.

For noninterest expenses (that is, operating expenses), we suppose that banks target cost ratios. This is supported by empirical estimates of an equation for noninterest costs based on the same aggregate U.S. data that were used to estimate noninterest income. Costs are found to be less procyclical than operating income, reflecting the proposition that banks are unable to immediately adjust expenses. The equation for operating expenses is

13. We also tried an error correction mechanism specification in an attempt to identify a long-run relationship, but it did not forecast as well as the dynamic equation. 


$$
\begin{aligned}
& \left(\frac{\text { Operating expense }}{\text { Operating income }}\right)_{t}=\underset{(2.16)}{0.053}+\underset{(23.64)}{0.920}\left(\frac{\text { Operating expense }}{\text { Operating income }}\right)_{t-1} \\
& -\underset{(1.45)}{0.487} d \ln \left(G D P_{t}\right) \text {, }
\end{aligned}
$$

where the adjusted $R$ squared is 0.86 , based on 94 observations.

\subsubsection{Profits, Taxes, and Dividends}

To generate plausible profit figures, we assume that each bank earns a trading income that is proportional to the size of its portfolio, using 2007 data to calibrate the ratio. This assumption will obviously become redundant when we introduce trading book and AFS models. Profits are then computed as the sum of all sources of income, net of expenses and credit losses. We deduct taxes and dividends from profits, assuming that the tax rate and ratio of dividends to profits are in line with recent history.

Profits (or losses) after taxes and dividends are assumed to increase (or erode) Tier 1 capital directly. Updated Tier 1 capital ratios may then be computed by dividing capital by risk-weighted assets, where the latter are computed by applying Basel II standardized risk weights or approximations to them when we have insufficient information (such as corporate loans, for which we do not know the ratings of the borrowers).

\subsection{Funding Liquidity Risk and Bank Failure}

The ongoing credit crisis has illustrated starkly how increased funding costs and the closure of funding markets can trigger bank failure. We have integrated two complementary channels to capture funding liquidity effects. First, we apply an empirical model to project individual bank ratings and use the results to calibrate how funding costs may change with the fundamentals of a bank. Second, we use a separate danger zone model in which a range of indicators determine whether a bank suffers stress so severe that it is shut out of unsecured funding markets.

We consider it important to model the outright closure of funding markets in a distinct framework. Figure 3 illustrate this point. Though there may be a relatively linear relationship between a deterioration in bank fundamentals and increased funding costs in 
relatively normal times, it is hard to use this approach to identify the closure of funding markets in extreme circumstances, given that this is an inherently nonlinear process and could occur at different ratings and funding costs (A or B), depending on the circumstances. We thus feel that the danger zone approach is more appropriate for identifying the region in which funding markets are likely to shut. Nevertheless, we intend to use the funding cost or ratings model as a cross-check on the danger zone approach.

\section{Figure 3. The Operation of Funding Liquidity Risk}

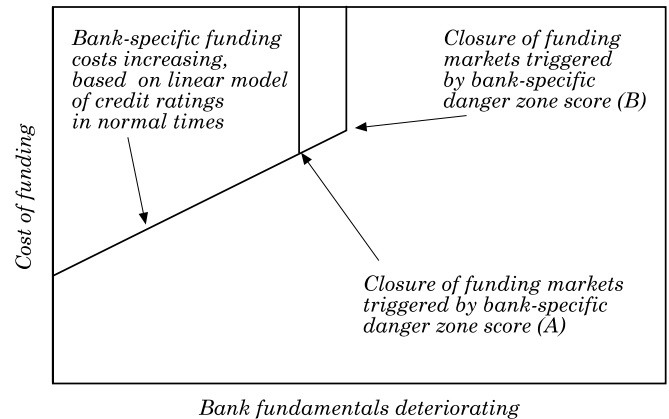

Source: Authors' drawing.

\subsubsection{Bank ratings and funding costs}

We model banks' funding costs in two stages. First, we use an ordered probit model (adapted from Pagratis and Stringa, 2008) to examine the sensitivity of Moody's senior (long-term) unsecured ratings to a number of key bank performance indicators and macroeconomic variables. The index produces ratings for each bank at each quarter using the estimated coefficients from table 3. Ratings are found to improve under the following conditions: (i) when profitability increases; (ii) when the ratio of (illiquid) customer loans to short-term liabilities is relatively low; (iii) when the bank has a relatively high market share of lending; (iv) when cost efficiency (proxied by operating expenses/total assets) is high; (v) when asset quality (proxied by credit losses/net interest income) is high; (vi) when economy-wide output and credit rise above trend and the yield curve steepens. 
The assigned ratings are mapped to credit spreads using Merrill Lynch's bond indices of U.K. sterling bond spreads associated with different credit ratings. These bank-specific spreads are applied to certain types of wholesale funding (including interbank and other nonretail deposits, commercial paper, certificates of deposit, and subordinated debt). This introduces a key feedback mechanism on the liability side of balance sheets: if a bank gets downgraded, the associated rise in its funding costs will reduce its future profitability, leaving it more vulnerable to future downgrades and, ultimately, to a loss of access to wholesale funding markets.

\subsubsection{Modeling the closure of funding markets: A danger zone approach}

Modeling the outright closure of funding markets presents significant challenges, both because of the binary, nonlinear nature of liquidity risk and because-notwithstanding recent eventsliquidity crises in developed countries are rare events for which data are limited. We therefore adopt a simple, transparent (yet subjective) danger zone approach, under which banks accumulate points as liquidity conditions deteriorate and face the prospect that certain funding markets may close to them as their score crosses particular thresholds.

Figure 4 gives an overview of the approach. Outputs from the rest of the model are mapped into specific indicators of funding stress relating to three key areas that theoretical models (such as Chen, 1999, and Goldstein and Pauzner, 2005) and evidence

\section{Figure 4. Closure of Funding Markets in RAMSI}

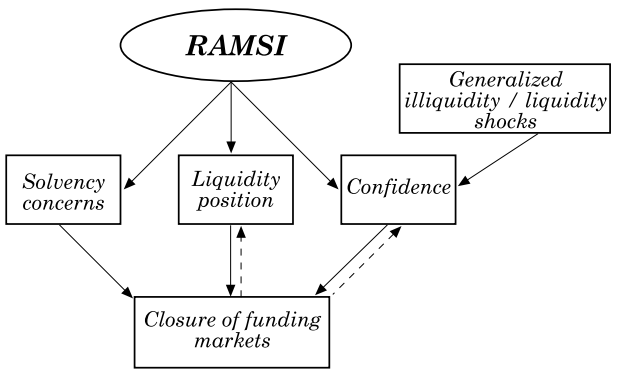




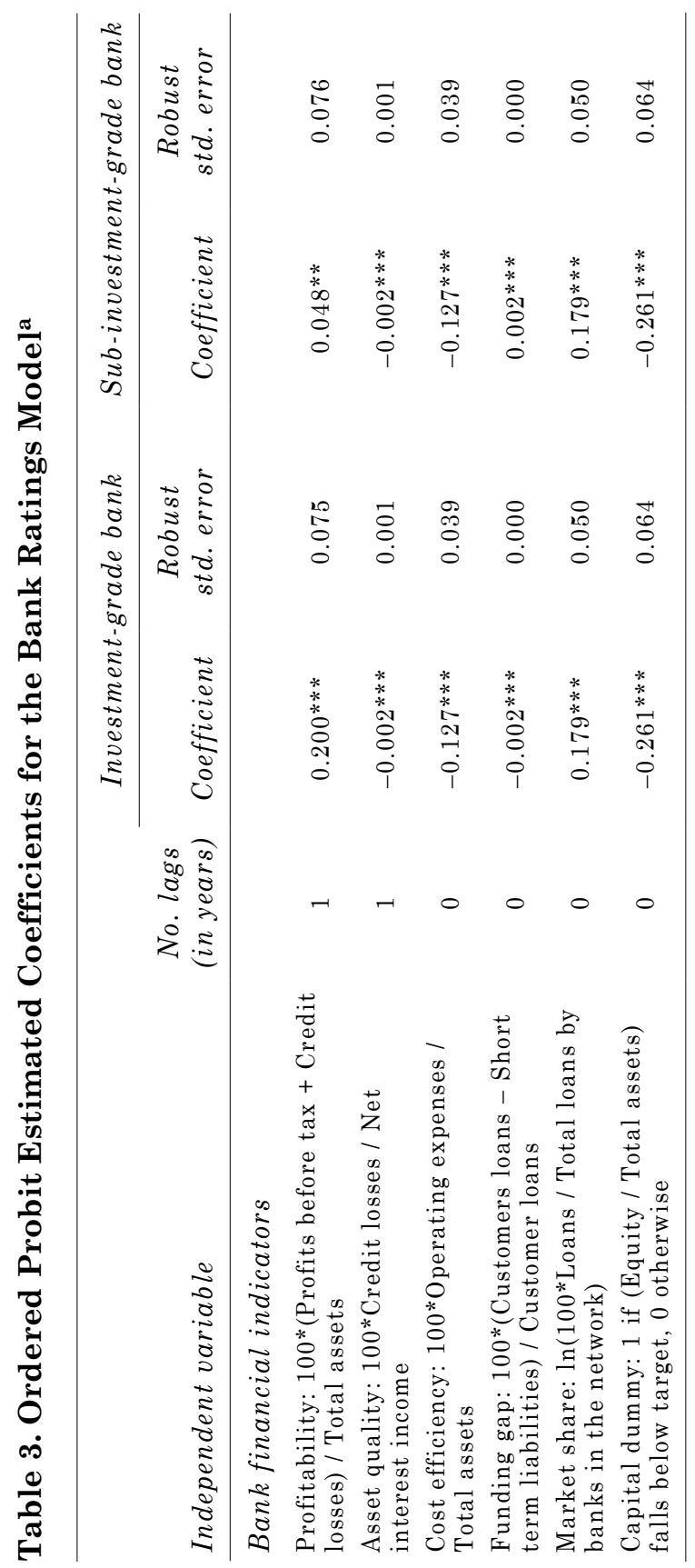




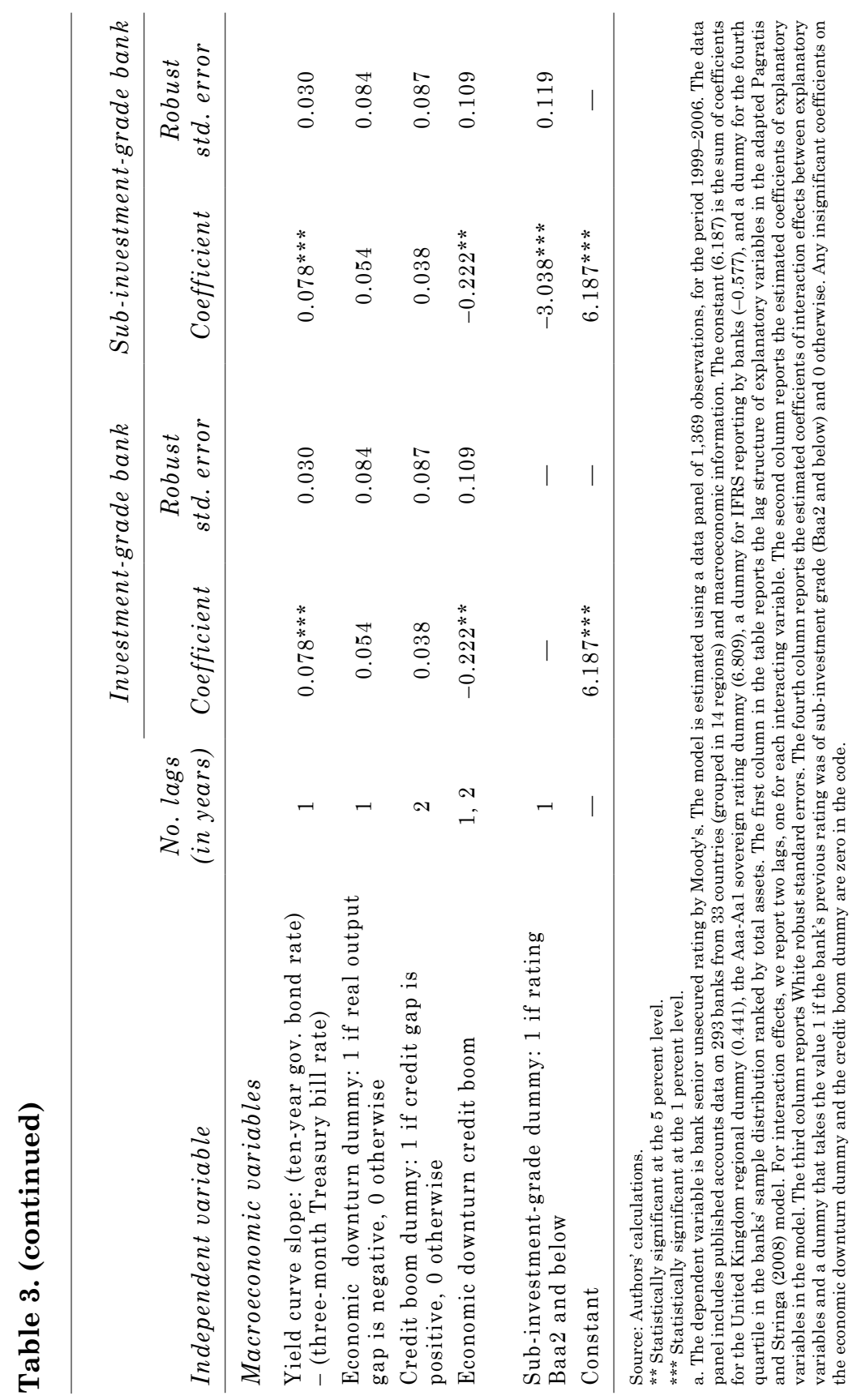


from case studies and banks' own liquidity policies suggest are important: namely, solvency, liquidity, and confidence. The framework allows for feedback effects. In particular, the closure of certain funding markets to an institution may worsen that bank's liquidity position through snowball effects, whereby the bank becomes increasingly reliant on short-term funding, and may adversely affect similar banks through a pure confidence channel. Recent events highlight how marketwide liquidity factors can also play an important role by affecting confidence and thus contributing to funding stress. To proxy for these factors, the framework captures a greater risk of funding stress in periods when the market interbank spread is elevated.

Figure 5 presents the set of eight indicators (with the underlying factor that each is trying to proxy in brackets), along with the aggregation scheme and the thresholds at which short- and long-term unsecured funding markets are assumed to close to the bank. ${ }^{14}$ In constructing the weighting, we place roughly equal weight on three main factors that can trigger a funding crises: (i) concerns about future solvency; (ii) a weak liquidity position or funding structure (for example, a high reliance on short-term wholesale unsecured funding); and (iii) institution-specific and marketwide confidence effects, over and above those generated by solvency concerns or weaknesses in liquidity positions. In the aggregation, we allow for the possibility that a run could be triggered either by extreme scores in any of the three areas or by a combination of moderate scores across the different areas. The judgments underpinning more specific aspects of the calibration and weighting schemes were informed by analysis of a range of case studies. ${ }^{15}$

Currently, the danger zones are incorporated into RAMSI in a simplified way. Since the model does not yet include model-consistent expectations, the current Tier 1 capital ratio is used instead of the expected ratio and the past profitability indicator is ignored, as it is not possible to identify unanticipated losses. The threshold at 25

14. Secured funding markets are discussed below. For simplicity, we do not consider a more detailed breakdown of funding markets (for example, we do not distinguish between foreign and domestic funding markets).

15. The case studies (still work in progress) include both episodes in which banks have failed (such as Franklin National Bank, Continental Illinois, Japanese banks, and Northern Rock) and episodes in which banks have survived (including Lehman Brothers during the LTCM crisis, Countrywide, and Société Générale following the recent fraud). 
Figure 5. Danger Zones: Basic Structure

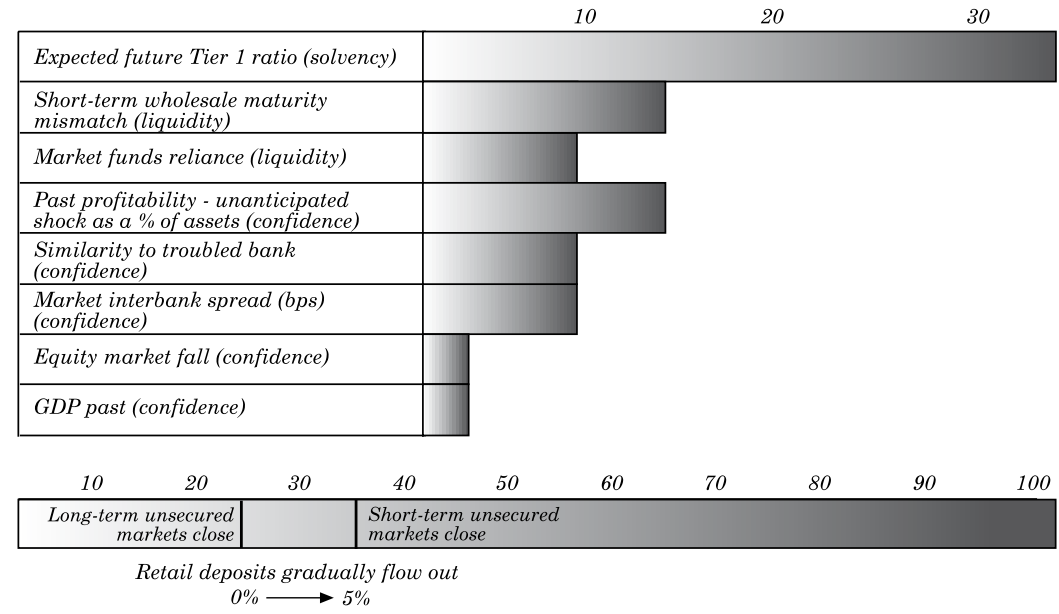

Source: Authors' drawing.

points is also ignored, and banks are simply assumed to default if their danger zone score reaches 35 and short-term secured markets close to them. When fully incorporated, a score of 25 or more will trigger the closure of long-term unsecured funding markets to the bank, which will be able to refinance in short-term unsecured funding markets or take other defensive actions such as selling or repoing assets. There will be no default at this point, but there will be a snowball effect, whereby the increased reliance on short-term funds will affect the bank's score on the maturity mismatch indicator.

The full danger zone framework will also allow for a number of extensions. First, there will be a gradual outflow of retail deposits after long-term unsecured funding markets close to the bank, such that the outflow reaches 5 percent of retail deposits by the time shortterm unsecured markets close. This is intended to reflect behavior of well-informed investors rather than a widespread run (like Northern Rock). Second, we intend to define banks scoring less than five points as safe and allow them to receive funding withdrawn from troubled banks; as such, they will help to close the system by capturing flight-to-quality effects. If there are no safe banks, we will assume funds end up as increased reserves at the central bank. Finally, we plan to extend the framework to cover secured funding markets. For 
these, we will assume that if a bank cannot repo assets, it will be able to sell them at the prevailing market price. Critically, however, this could be a fire-sale price and, in some instances, could even be zero, either because there are no buyers in the market or because of potential stigma effects that could be generated by a large asset sale in an illiquid market. The framework will thus highlight the importance of collateral quality in determining how a bank fares if secured funding markets close to it.

\subsubsection{Example of a danger zone calibration: Continental Illinois}

Case studies indicate that the danger zone approach performs relatively well, especially in terms of capturing the ranking of institutions that are under the most stress. We have considered case studies beyond the very recent crisis. An example is the case of Continental Illinois, which can be divided into two periods, at least in terms of funding liquidity pressure: the closure to it of longer-term domestic funding markets in July 1982 and the global run in May 1984. Figure 6 scores Continental Illinois in each of these periods.

\section{Figure 6. Continental Illinois Danger Zone Points}

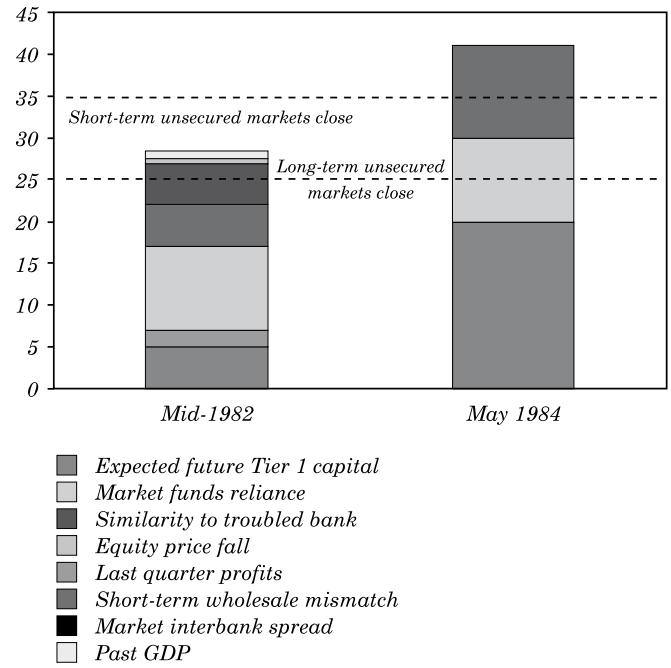


Continental scores heavily on the market funds reliance indicator, but solvency concerns also played a crucial role. In particular, the July 1982 run may be identified with mild concerns over future solvency stemming from anticipated losses on risky speculative loans to the energy sector. Many of these loans had been originated by Penn Square, a much smaller bank that failed earlier that month.

Aside from raising solvency concerns, Continental scores points following Penn Square's failure both because of its similarity and because of a significant unanticipated loss from a direct exposure. Overall, Continental scores enough points for the first danger zone threshold to be crossed. Increased reliance on short-term funding then serves to increase Continental's score over the next couple of years. The final trigger for the second run is the fallout from the Latin American debt crisis-which substantially raised future solvency concerns during the first part of 1984 so that by May, Continental exceeds the second danger zone threshold.

\subsubsection{Bank failure and bankruptcy costs}

As just discussed, banks are assumed to default if they score 35 danger zone points and are shut out of short-term unsecured funding markets. When a bank defaults, we follow James (1991) and suppose that it incurs costs equivalent to 10 percent of its remaining assets. This is also in line with the mean figure reported in Bris, Welch, and Zhu (2006). These bankruptcy costs are designed to capture the direct legal, accounting, and redundancy costs that are incurred upon default. They may also be viewed as capturing the erosion in the real value of a bank's assets that may occur upon default as a result of disruptions to established bank-borrower relationships or the loss of human capital. They imply that even if banks fail with positive shareholder funds, they will be unable to fulfil all of their obligations upon default.

\subsection{Second-Round Effects and Contagion}

In this section, we assess various channels of systemic feedback that occur when a distressed bank fails. These occur on both the asset and liability side of banks' balance sheets. 


\subsubsection{Asset-side feedbacks: Fire sales}

When a bank is in distress, it may sell assets, opening up the possibility of an important feedback channel operating via asset prices. In the current version of RAMSI, such fire sales only occur after a bank defaults, and not as a defensive action to stave off failure. A failing bank is assumed to liquidate all its available-forsale (AFS) assets. The fire-sale discount lasts for one quarter, and the resulting fall in asset prices may lead other banks to incur markto-market losses; hence in extreme circumstances, these banks may then also fail.

The associated price impact given by equation (4) is applied to other banks' AFS assets. Consistent with Duffie, Gârleanu, and Pedersen (2006), we take the relationship between prices and the magnitude of fire sales to be concave. For asset $j$, the fire-sale equation is

$$
P_{j}^{\prime}=\max \left\{0, P_{j}\left[2-\exp \left(\theta \frac{S_{i j}}{M_{j}+\varepsilon_{j}}\right)\right]\right\} .
$$

The price of asset $j$ following the fire sale, $P_{j}^{\prime}$, is the maximum of zero and the price before the fire sale, $P_{j}$, multiplied by a discount term. The discount term is a function of the value of assets sold by bank $i$ in the fire sale, $S_{i j}$, divided by the depth of the market in normal times, $M_{j}$, and scaled by a parameter $\theta$ that reflects frictions, such as search problems, that cause markets to be less than perfectly liquid. Market depth can also be shocked by a term $\varepsilon_{j}$ to capture fluctuations in the depth of markets as macroeconomic conditions vary. There are three types of assets that can be affected by fire sales: equities, corporate debt securities, and asset- and mortgage-backed securities. Each has a different value of market depth.

Calibration of the parameters is made difficult by the paucity of empirical analyses that reveal the price impact for a given volume of assets sold in fire sales. Our calibration is guided, in part, by Mitchell, Pedersen, and Pulvino (2007), who consider a fire sale of U.S. convertible bonds by hedge funds in 2005. They estimate that 5 percent of the outstanding stock of U.S. convertible bonds were sold at a maximum price discount of 2.7 percent. Similarly, Coval and Stafford (2007) analyze the price impact of fire sales involving U.S. equity mutual funds. They find an average price 
impact of 2.2 percent for the fire sales they identify. Pulvino (1998) focuses on fire sales of aircraft and finds larger price impacts for these assets. He also finds that the price impact varies when the depth of the market fluctuates. However, none of this information is sufficient for precise calibration, since it is not possible to make a direct comparison of the size of the fire sale in relation to the overall market in the study and the potential size in the case of any liquidation of U.K. banks' assets.

Therefore, the calibration is guided both by this empirical evidence and a top-down judgment regarding the plausible impact of a fire sale on capital. ${ }^{16}$ The calibration for $\theta$ is based on the results presented in Mitchell, Pedersen, and Pulvino (2007). Given $\theta$, a value of market depth $M_{j}$ is chosen for each of the asset types so that when the U.K. bank with the largest holdings of an asset class in its trading portfolio and AFS assets sells all these assets, it generates prices falls of 2 percent for equities, 4 percent for corporate debt, and 5 percent for asset- and mortgage-backed securities.

\subsubsection{Network model}

When a bank defaults, counterparty credit losses incurred by other banks are determined using a network model. A matrix of interbank exposures for the major U.K. banks, along with some smaller U.K. institutions and a selection of large, complex financial institutions (LCFIs) is built using reported large exposure data where available. Since we also have information on total interbank asset and liability positions, we then use maximum entropy techniques to fill in missing gaps in the network, ensuring that none of the estimated entries exceed the reporting threshold for large exposures. ${ }^{17}$ If any interbank assets or liabilities are unallocated following this procedure, we assume that they are associated with a residual sector that cannot default. Once constructed, the estimated exposure matrix remains static over the forecasting horizon. To clear the network following the default of one or more institutions, we use the Eisenberg and Noe (2001) algorithm. This both determines contagious defaults and returns counterparty credit losses for each institution.

16. The impact is likely to be stronger when the financial system is under stress and markets are less deep (Pulvino, 1998).

17. The techniques adopted are similar to those discussed by Wells (2004), Elsinger, Lehar, and Summer (2006b), and Boss and others (2006). 


\subsubsection{Feedback loop}

After accounting for counterparty credit losses and mark-to-market losses on AFS assets, we update the danger zone scores for banks that survived initially (see figure 2). In the event of another bank breaching the 35-point threshold, we iterate around the network and asset-side feedback mechanism again. If no banks breach the threshold, we update all balance sheets to account for counterparty credit losses. However, we assume that asset prices recover to prefeedback levels, so mark-to-market losses are not carried forward. This reflects the idea that once a crisis has passed, asset prices are likely to return to their fundamental values fairly quickly. A more gradual price adjustment process would impose higher systemic costs on the banking system, and we plan to allow for this in future work.

\subsection{Reinvestment}

Rules for adjusting balance sheets to account for profits and losses are necessary in a multi-period setting. As noted above, profits (or losses) after taxes and dividends are assumed to increase (or erode) Tier 1 capital. On the asset side, credit losses are simply booked against the relevant exposure for the loss. But other profit and loss items cannot be linked so directly to particular balance sheet lines. Therefore, to rebalance the balance sheet, we adopt a set of mechanical reinvestment rules. ${ }^{18}$ If operating income (which includes net interest income, noninterest income, and trading income) exceeds operating expenses, then at the point of rebalancing, liabilities plus capital will exceed assets, and banks reinvest their surplus funds according to the following rules:

-Rule 1: Banks have a bank-specific target Tier 1 capital ratio that they aim to meet when investing their funds (and they are not permitted to buy back equity to meet their target);

-Rule 2: Subject to rule 1, banks invest in assets in proportion to their shares on the bank's initial balance sheet (for example, mortgage banks will, ceteris paribus, invest in mortgage assets rather than trading assets);

-Rule 3: Rule 1 determines total assets after reinvestment and hence the amount of new liabilities that need to be raised; these

18. Rules can be respecified in policy experiments (for example, to assess the impact of targeting leverage or of raising capital). 
net new liabilities are allocated in proportion to their shares on the bank's initial balance sheet.

In the current version of RAMSI, defensive actions in response to declines in capital are very limited. When a bank's operating expenses exceed its operating income (so that assets exceed liabilities plus capital at the point of rebalancing), we assume that the bank is unable to disinvest or raise capital. Rather, it raises new liabilities according to rule 3 . The reinvestment rule therefore has the benefit of transparently demonstrating the implications of not taking mitigating actions in the face of losses. This is not necessarily realistic, however. For example, an alternative specification would allow banks to disinvest when making losses; this would reduce the likelihood of the bank suffering a liquidity crisis, but it would introduce a further channel of macroeconomic feedbacks.

The primacy of the Tier 1 capital ratio rule is justifiable, first, because five U.K. banks (namely, Barclays, Bradford and Bingley, Halifax Bank of Scotland, HSBC, and Royal Bank of Scotland) publish a Tier 1 capital ratio target; and, second, because the mean ratio of capital to risk-weighted assets for the major U.K. banks was relatively stable in recent years (up to 2007) and institution-specific standard deviations of this ratio were low. For banks that have not published target capital ratios, we assume that they target a capital ratio equal to their end-2007 number.

We are motivated to choose neutral assumptions regarding portfolio allocation, and the second and third rules are based on the presumption that initial balance sheets represent desirable equilibrium outcomes that banks seek to preserve in the face of changes in size. Drastic changes in portfolio are typically associated with a change in the bank's business model. Within a given business model, the rules seem reasonable, especially over the three year horizon considered in this paper.

The portfolio allocation rules are not entirely neutral, however. The liability rule precludes banks from responding to changes in funding costs. On the asset side, our assumed rule precludes the possibility that banks may skew their reinvestment toward areas in which they have recently been most profitable, which may understate the risk. Following positive macroeconomic outcomes, risky assets tend to generate the most profits and increase most in value. Risks would therefore accumulate more quickly were we to employ an alternative reinvestment rule in which banks reinvested profits in proportion to the nominal value of assets held 
on the balance sheet in the most recent period (rather than the initial period in our rule). We intend to conduct further validation to guide such choices.

There is no leverage target, so our reinvestment rules allow leverage to be determined according to developments elsewhere in RAMSI. As pointed out by Adrian and Shin (2008), leverage may be procyclical when positive macroeconomic outcomes lead to a decline in the measured riskiness of banks' existing assets (such as a decline in value at risk or a fall in Basel II risk weights). Such procyclicality will be built into RAMSI when we introduce endogenous Basel II risk weights that adjust to changes in PDs. Conversely, if banks choose to purchase relatively risky assets (with high risk weights), then leverage rises relatively less, since banks can achieve their Tier 1 capital ratio targets by purchasing fewer assets than if they purchase assets with lower or zero risk weights, such as government bonds.

\section{Simulations}

We use data up to the fourth quarter of 2007 (so that all balance sheet information is on the basis of end-2007 data) and run 500 simulations on a three-year forecast horizon stretching to the end of 2010. The BVAR is currently the only source of exogenous randomness in the stochastic simulations; each simulation is thus driven by a sequence of macroeconomic shocks drawn from a multivariate normal distribution. ${ }^{19}$ It should be stressed, however, that the results are illustrative, reflecting model properties in this preliminary version rather than being the authors' view of likely responses of the banks in question.

\subsection{Aggregate Results}

Throughout this section, we discuss results for the U.K. banking system in aggregate. Since individual banks' balance sheets are at the core of RAMSI, the model produces a rich set of information and may be used both to obtain baseline projections for specific institutions and to analyze their performance under stress. Such

19. In other words, we draw 500 realizations of the macroeconomic risk factors in the first quarter. In subsequent periods, we draw a single set of macroeconomic risk factors for each of the 500 draws. 
information can be used to assess the vulnerability of particular institutions to different risks and may thus feed into the internal institution-specific risk assessment work undertaken by regulators and central banks.

Figure 7 shows the simulated distributions of some key profit and loss items. For each variable, we calculate aggregate cumulative figures for the first year by adding over banks and quarters, and we normalize by aggregate 2007 capital (that is, by capital at the beginning of the period). The vertical line represents the corresponding figures from the 2007 published accounts, normalized by 2006 capital levels.

Figure 7. Simulated Distributions for Profit and Loss Items ${ }^{\mathrm{a}}$ Percent of aggregate 2007 capital

A. Credit losses

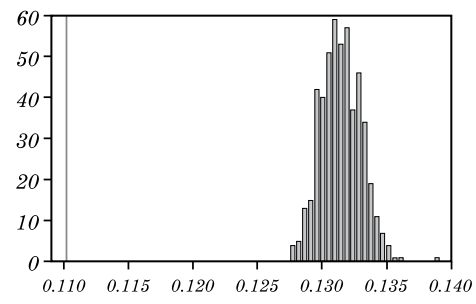

C. Noninterest income less trading income

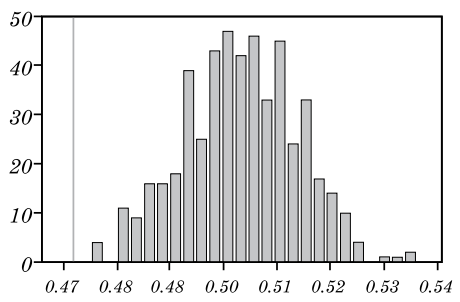

B. Net interest income

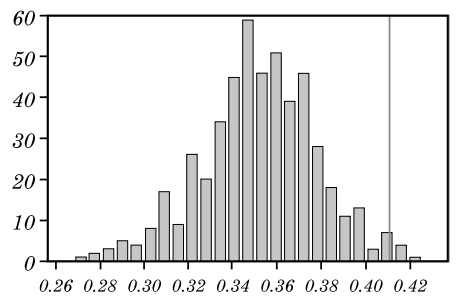

D. Net profit before tax

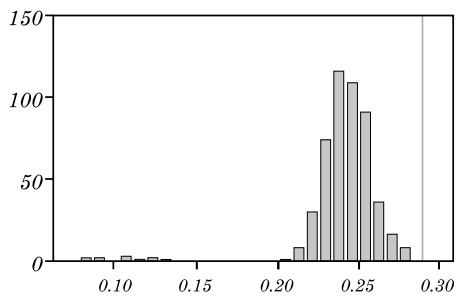

Source: Authors' calculations.

a. All items are cumulative for the first forecast year.

Panel A shows that credit risk is projected to increase in 2008 , reflecting a worsening of the macroeconomic outlook. However, since our credit risk model abstracts from portfolio concentrations (see section 1.3.1), we arguably underestimate the variance of the credit 
risk loss distribution. Net interest income is projected to be weaker than 2007, reflecting contractual frictions that prevent banks from instantaneously passing on higher funding costs to their borrowers. The variance of net interest income may be unrealistically high, as the model does not incorporate hedging of interest rate risk. ${ }^{20}$ Noninterest income (panel C) remains high, with a median projection above the reported 2007 level; this variable is procyclical, but it adjusts relatively slowly to macroeconomic changes. The net impact on banks' profitability is summarized in the net profit chart (panel D). Profits were projected to be weaker than in 2007, and there is some evidence of bimodality, insofar as there are a number of observations in the extreme tail of the distribution, which are typically associated with one or more banks defaulting.

\subsection{Dissecting the Tail: The Role of Funding Liquidity and Contagion}

The crisis afflicting banks in the U.K. and internationally has illustrated the importance of funding liquidity. By their nature, the aggregate cumulative distributions in figure 7 mask bank-by-bank heterogeneity. In bad draws taken from the BVAR, some banks incur large losses in some quarters or scenarios, which can erode those banks' Tier 1 capital ratios and increase their danger zone points. With some banks scoring points on the liquidity indicators, the increased solvency concerns can, in extreme cases, be sufficient for a bank's score to reach 35 points, leading to the closure of short-term unsecured funding markets to that institution and its default. Note that the introduction of funding liquidity risk into the framework is critical here. Looking at capital alone, the defaulting banks remain well above the 4 percent regulatory minimum. Nevertheless, a combination of mild solvency concerns, a weak liquidity position, and elevated market interbank spreads is sufficient for wholesale depositors to withdraw funding.

The crosses in figure 8 show danger zone scores for a defaulting bank. The bank fails because it scores points on a range of indicators, including the Tier 1 capital ratio indicator, but its weak liquidity position, captured in the second and third indicators, contributes to its failure. As such, it is clear that the inclusion

20. Banks can be penalized under the second pillar of Basel II for not hedging interest rate risk. 
of danger zones in the framework makes banks more vulnerable. The results accord with reality in the sense that funding liquidity crises are triggered by a mixture of factors and can occur even if the bank is perceived to be solvent.

\section{Figure 8. Danger Zone Scores for a Defaulting Bank}

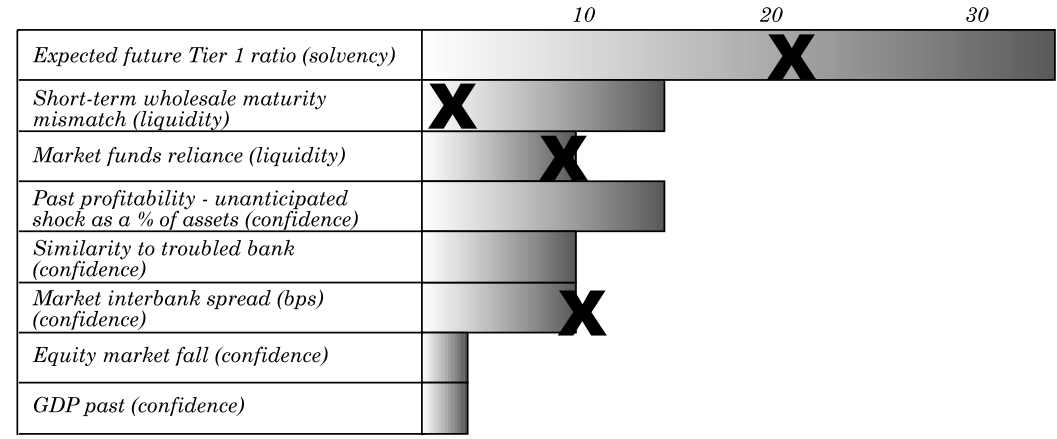

\begin{tabular}{|c|c|c|c|c|c|c|}
\hline 20 & 30 & 50 & 60 & 70 & 80 & 90 \\
\hline $\begin{array}{r}\text { Long-term unsecured } \\
\text { markets close }\end{array}$ & & $\begin{array}{l}\text { Short-term unsecured } \\
\text { markets close }\end{array}$ & & & & \\
\hline
\end{tabular}

Source: Authors' drawing.

Contributing to bank heterogeneity are bank-specific funding spreads that depend on bank ratings. A bank is more likely to be downgraded as profitability falls and its capital falls below target. This serves to raise its funding costs, hurting profits further and making the bank more vulnerable to subsequent default. We observe this feedback relationship in figure 9. The figure shows two distributions for bank rating changes at the end of the forecast horizon or at the point of default, relative to the initial rating. The total number of observations is therefore 500 simulations multiplied by ten banks. The light-shaded distribution is for scenarios in which the bank does not default, and the black-shaded distribution is for scenarios in which the bank defaults. As we expect, the default distribution has more of its mass at lower ratings than does the nondefault distribution. 


\section{Figure 9. Rating Distribution: Cumulative Change ${ }^{\text {a }}$}

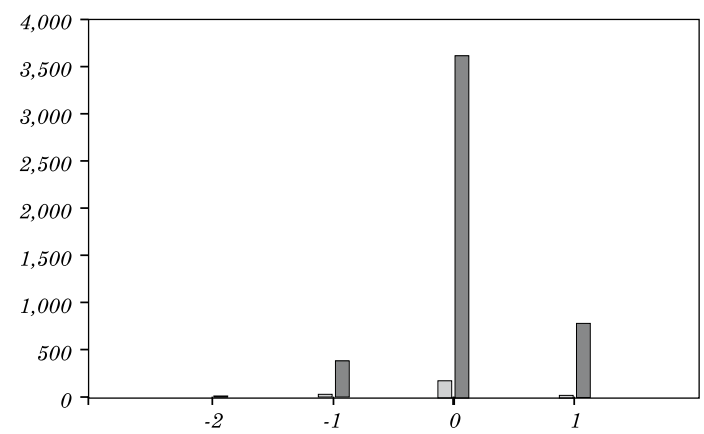

Source: Authors' calculations.

a. Bank scenarios for the twelfth quarter, relative to the initial distribution. Gray bars represent ratings for nondefaulting bank scenarios; black bars depict ratings for defaulting bank scenarios.

Figure 10 shows the distribution of total assets in the last quarter of the simulation and the average aggregate return on assets (RoA) over the whole horizon. These figures highlight the role of contagion in RAMSI. The distributions are bimodal, with a main peak associated with a healthy banking sector and a considerably smaller second peak in the left tail. ${ }^{21}$ This is a direct consequence of bankruptcy costs and, in particular, network and asset-side liquidity feedbacks: since fundamental defaults can generate contagion, extreme negative outcomes become relatively more likely beyond a certain threshold than moderate negative outcomes. This result captures a phenomenon that is commonly perceived as a key feature of financial risk.

The extent to which there is contagion in simulations in the left tail is highlighted by the evolution of the danger zone points. For example, table 4 presents the build up of points for two other banks following the failure of the bank shown in figure 8. As already discussed, this bank (Bank 1) defaults in a fundamental sense because it receives a danger zone score greater than 35 . Prior to the failure of Bank 1, Bank 2 only has a danger zone score of 26.5. However, it is perceived to be so similar to Bank 1 that it is tipped into default by this pure confidence effect. Contagion

21. The bimodality is qualitatively robust and crucial feature of the model. See Alessandri and others (2009) for more discussion of this bimodality. 


\section{Figure 10. Total System Assets and Return on Assets}

\section{A. Total system assets: Final forecast quarter}

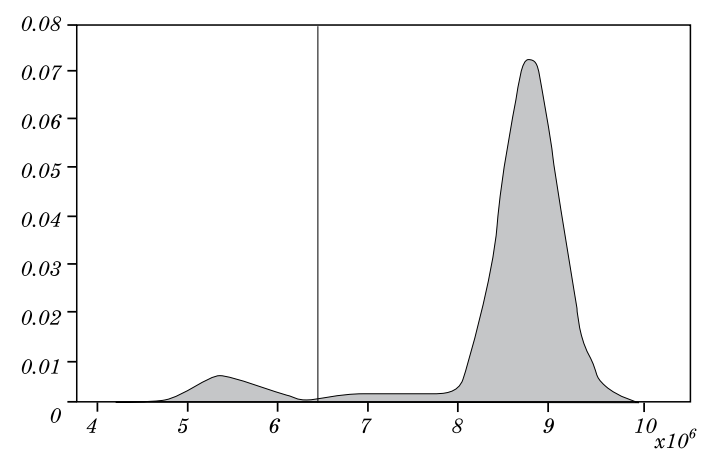

B. Return on assets: Twelve-quarter mean

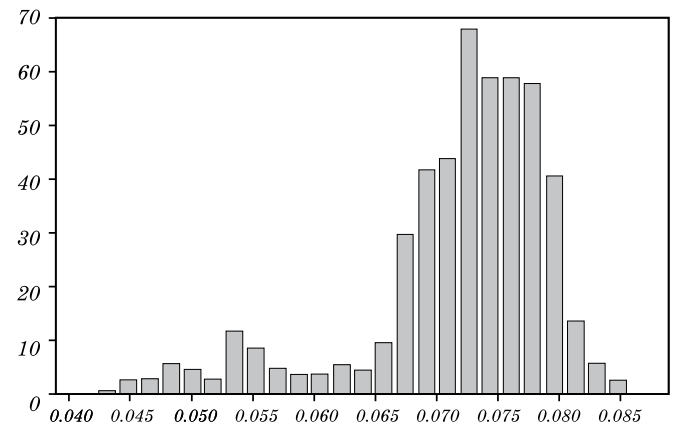

Source: Authors' calculations.

then extends to Bank 3, which also suffers because of its perceived similarity to the failed banks. Moreover, the failure of Bank 2 and the associated fire sale of its assets cause Bank 3 to incur significant interbank and mark-to-market losses that eat into its capital. Indeed, of all the banks in the network, Bank 3 suffers the greatest counterparty credit loss as a percentage of its Tier 1 capital prior to the default of Bank 1 as a result of the failure of Bank 2. Both interbank and mark-to-market losses triggered by fire-sales are important sources of contagion. This process clearly illustrates how funding liquidity problems at one bank can spread to other banks in tail simulations. 


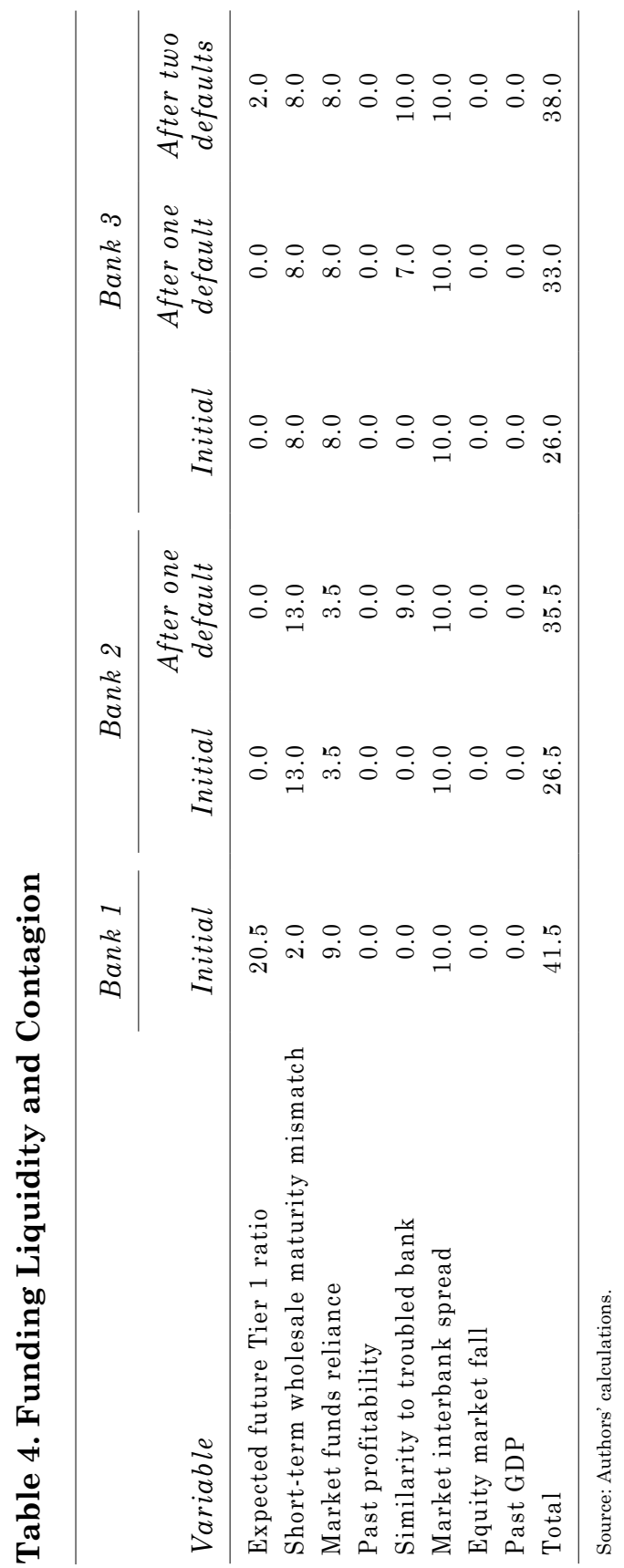




\section{Policy Applications}

The ultimate goal for RAMSI is to sharpen and add analytical rigor to the Bank of England's risk assessment work. To be successful, the model must provide a well-grounded narrative of how potential risks may play out. And to improve external communication, it needs to use metrics that are familiar to supervisors and risk managers. This section assesses some channels through which improvements will transpire and highlights some further issues in using RAMSI for policy analysis.

-Fan charts: Aggregate and bank-specific fan charts will be developed for a wide variety of financial variables (including losses, lending, credit spreads, and so on). ${ }^{22}$ In producing fan charts, we face a potential trade-off. On the one hand, there are benefits from improving the accuracy of our fan charts by including additional sources of randomness to that arising from the BVAR, for example, from the PD equations and liquidity risk. Such a distribution is arguably more likely to resemble that produced by commercial banks' own risk managers. On the other, increasing the number of sources of randomness greatly increases model run times and breaks the direct mapping from macroeconomic scenarios to outcomes, thus reducing the clarity of story-telling.

- Stress testing: RAMSI will be of particular use in providing model-based estimates of the impact of the risks highlighted in the Bank of England's Financial Stability Report (FSR). It will also be useful for running stress tests on the stability of the banking system under different stress scenarios. Relative to traditional stress tests, RAMSI integrates more of the channels through which shocks could propagate and takes account of the contagion that may occur through interbank exposures, asset fire sales, funding liquidity, and macroeconomic feedbacks. Assessment of the second-round effects has been identified by Haldane (2009) as an important area for development of stress testing in the financial system.

-Assessing sources of risk to banks: RAMSI will provide the relative contributions to overall risk of the various modules (credit

22. RAMSI's outputs may be used to provide alternative metrics of financial stability by recalibrating the reinvestment rule. To gauge declines in credit supply, it would be necessary to specify a reinvestment rule in which banks respond to losses by taking defensive actions, including reducing loans. Conversely, suppressing such mitigating actions would be a sensible option for assessing the potential for individual bank failures. 
risk, market risk, funding risk, interest income risk, and other risks). In particular, RAMSI may be used to assess the contribution of systemic feedbacks to overall risk.

-Intermediate outputs: A number of RAMSI's outputs may be useful analytical tools, even when used in isolation from the rest of RAMSI. Examples include balance sheets, the credit loss model, the net interest income model, the ratings model, and the danger zone scores for funding liquidity crises.

-Policy design: RAMSI can be used for counterfactual experiments in which regulatory changes could affect systemic risk. ${ }^{23}$ For example, we could analyze regulations that require banks to hold more capital or liquid assets or to vary their holdings across the cycle. The impact on risk and profitability can be observed on either a bank-by-bank or an aggregate basis. The modular approach also affords the possibility of measuring the potential benefits of diversification for each bank.

-Recapitalization: RAMSI could be used to calibrate the extent to which the recent recapitalization of the U.K. banking system reduces systemic risk.

\section{Conclusion and Further Work}

This paper incorporates funding liquidity risk into a quantitative model of systemic stability. By applying the model to the U.K. banking system based on the balance sheet vulnerabilities that existed at the end of 2007, we demonstrate how rising funding costs and liquidity concerns can amplify other sources of risk. The unified modeling approach sheds light on risks arising throughout banks' balance sheets. It also demonstrates how defaulting financial institutions may cause contagion by triggering default cascades through the interbank market; the sale of assets at fire-sale prices; and through the erosion of confidence in other banks.

We intend to develop the model in a number of areas. A substantial area for further work is to analyze banks' cash flow constraints and consider how defensive actions in the face of funding

23. See, for example, Goodhart (2008). Procyclicality will, to some extent, be built into the baseline of RAMSI when we introduce Basel II dynamic risk weights, which adjust to changes in the probability of defaults. In addition to the regulatory experiments above, RAMSI can allow for the possibility of procyclicality in terms of profits being reinvested in the most profitable (and risky) parts of the balance sheet. 
stress may affect the rest of the financial system and the wider macroeconomy. In principle, macroeconomic feedbacks could be introduced by linking the realized banking-sector lending response to the price and quantity of loans in the BVAR, though we need to do more work to determine a coherent framework for embedding this important transmission channel. A further area for development will be to introduce more sources of randomness in the model beyond the BVAR (for example, in PDs). Such developments would clearly add to the computational complexity of RAMSI, but they would improve the realism of the various fan chart summaries of outcomes.

RAMSI has been one of the largest analytical projects at the Bank of England, and it will go live in 2009. Ultimately, its future development will largely be determined by the aspects of RAMSI that the Bank of England finds most useful in enhancing its understanding and communication of financial vulnerabilities. Our hope is that the analytical framework RAMSI provides will become central to the analysis of systemic risk in the United Kingdom and perhaps in other countries, as well. 


\section{REFERENCES}

Adrian, T. and H.S. Shin. 2008. "Liquidity, Monetary Policy, and Financial Cycles." Current Issues in Economics and Finance 14(1): 1-7. Federal Reserve Bank of New York.

Alessandri, P., P. Gai, S. Kapadia, N. Mora, and C. Puhr. 2009. "Towards A Framework for Quantifying Systemic Stability." International Journal of Central Banking 5(3): 47-81.

Allen, F. and D. Gale. 2000. "Financial Contagion." Journal of Political Economy 108(1): 1-33.

Bank of England. 2007. Financial Stability Report, Issue 21. London.

Birchler, U. and M. Facchinetti. 2007. "Self-Destroying Prophecies? The Endogeneity Pitfall in Using Market Signals as Triggers for Prompt Corrective Action.” Working paper. Basel: Bank for International Settlements, BIS Research Task Force.

Boss, M., G. Krenn, C. Puhr, and M. Summer. 2006. "Systemic Risk Monitor: Risk Assessment and Stress Testing for the Austrian Banking System." Financial Stability Report 11 (June): 83-95. Vienna: National Bank of Austria.

Bris, A., I. Welch, and N. Zhu. 2006. "The Costs of Bankruptcy: Chapter

7 Liquidation versus Chapter 11 Reorganization." Journal of Finance 61(3): 1253-303.

Bunn, P., A. Cunningham, and M. Drehmann. 2005. "Stress Testing as a Tool for Assessing Systemic Risks." In Financial Stability Review, Issue 18, Bank of England, pp. 116-26.

Chen, Y. 1999. "Banking Panics: The Role of the First-Come, FirstServed Rule and Information Externalities." Journal of Political Economy 107(5): 946-68.

Cifuentes, R., G. Ferrucci, and H.S. Shin. 2005. "Liquidity Risk and Contagion." Journal of the European Economic Association 3(2-3): 556-66.

Coval, J. and E. Stafford. 2007. "Asset Fire Sales (and Purchases) in Equity Markets." Journal of Financial Economics 86(2): $479-512$.

DeYoung, R. and T. Rice. 2004. "How Do Banks Make Money? The Fallacies of Fee Income." Economic Perspectives 28 (fourth quarter): 34-51. Federal Reserve Bank of Chicago.

DNB (De Nederlandsche Bank). 2006. "Financial Stability: Is the Dutch Financial Sector Stress Resistant?" DNB Quarterly Bulletin 06 (December): 35-41. 
Drehmann, M., S. Sorensen, and M. Stringa. 2008. "The Integrated Impact of Credit and Interest Rate Risk on Banks: An Economic Value and Capital Adequacy Perspective.” Working paper 339. London: Bank of England.

Duffie, D., N. Gârleanu, and L. H. Pedersen. 2006. "Valuation in Overthe-Counter Markets." Working paper 12020. Cambridge, Mass.: National Bureau of Economic Research.

Eisenberg, L. and T. Noe. 2001. "Systemic Risk in Financial Systems." Management Science 47(2): 236-49.

Elsinger, H., A. Lehar, and M. Summer. 2006a. "Risk Assessment for Banking Systems." Management Science 52(9): 1301-14.

—. 2006b. "Using Market Information for Banking Systems." International Journal of Central Banking 27(1): 137-65.

Foglia, A. 2009. "Stress Testing Credit Risk: A Survey of Authorities' Approaches." International Journal of Central Banking 5(3): 9-46.

Frisell, L., M. Holmfeldt, O. Larsson, M. Omberg, and M. Persson. 2007. "State-Dependent Contagion Risk: Using Micro Data from Swedish Banks." Paper prepared for the conference on Developing a Framework to Assess Financial Stability. Bank of Canada, 6-8 November.

Gai, P. and A. Haldane. 2007. "Public Policy in an Era of SuperSystemic Risk." London: Bank of England.

Gai, P. and S. Kapadia. 2010. "Contagion in Financial Networks." Proceedings of the Royal Society A 466: 2401-23.

Gai, P., S. Kapadia, S. Millard, and A. Perez. 2008. "Financial Innovation, Macroeconomic Stability, and Systemic Crises." Economic Journal 118(527): 401-26.

Gieve, J. 2006. "Financial System Risks in the United Kingdom: Issues and Challenges." Bank of England Quarterly Bulletin 46(3): 337-41.

Goldstein, I. and A. Pauzner. 2005. "Demand-Deposit Contracts and the Probability of Bank Runs." Journal of Finance 60(3): 1293-327.

Goodhart, C.A.E. 2008. "The Regulatory Response to the Financial Crisis." Special paper 177. London School of Economics, Financial Markets Group.

Goodhart, C.A.E., P. Sunirand, and D. Tsomocos. 2006. "A Model to Analyse Financial Fragility." Economic Theory 27(1): 107-42.

Gray, D.F., R.C. Merton, and Z. Bodie. 2007. "New Framework for Measuring and Managing Macrofinancial Risk and Financial Stability.” Working paper 13607. Cambridge, Mass.: National Bureau of Economic Research. 
Hagen, J., A. Lund, K.B. Nordal, and E. Steffensen. 2005. "The IMF"s Stress Testing of the Norwegian Financial Sector." Norges Bank Economic Bulletin 76: 202-11.

Haldane, A. 2009. "Why Banks Failed the Stress Test." Paper prepared for the Marcus-Evans Conference on Stress Testing. Bank of England, London, 9-10 February.

Haldane, A., S. Hall, and S. Pezzini. 2007. "A New Approach to Assessing Risks to Financial Stability." Financial stability paper 2. London: Bank of England.

James, C. 1991. "The Losses Realized in Bank Failures." Journal of Finance 46(4): 1223-42.

Jenkinson, N. 2007. "Developing a Framework for Stress Testing of Financial Stability Risks." Paper prepared for the High Level Conference on Simulating Financial Instability. European Central Bank, Frankfurt, 12-13 July.

Litterman, R. 1986. "Forecasting with Bayesian Vector Autoregressions:

Five Years of Experience." Journal of Business and Economic Statistics 4(1): 25-38.

Mitchell, M., L.H. Pedersen, and T. Pulvino. 2007. "Slow Moving Capital." American Economic Review 97(2): 215-20.

Pagratis, S. and M. Stringa. 2008. "Modelling Bank Senior Unsecured Credit Ratings: A Reasoned Structured Approach to Bank Credit Assessment." London: Bank of England.

Pulvino, T. 1998. "Do Asset Fire Sales Exist? An Empirical Investigation of Commercial Aircraft Transactions." Journal of Finance 53(3): 939-78.

Segoviano, M.A. and P. Padilla. 2006. "Portfolio Credit Risk and Macroeconomic Shocks: Application to Stress Testing under DataRestricted Environments." Working paper 06/283. Washington: International Monetary Fund.

Stiroh, K. 2004. "Diversification in Banking: Is Noninterest Income the Answer?" Journal of Money, Credit, and Banking 36(5): 853-82.

Sveriges Riksbank. 2007. Financial Stability Report, 2/2007. Stockholm.

Vlieghe, J. 2001. "Indicators of Fragility in the U.K. Corporate Sector." Working paper 146. London: Bank of England.

Wells, S. 2004. "Financial Interlinkages in the United Kingdom's Interbank Market and the Risk of Contagion." Working paper 230. London: Bank of England.

Whitley, J., R. Windram, and P. Cox. 2004. "An Empirical Model of Household Arrears." Working paper 214. London: Bank of England. 